\title{
Potensi dan Masalah Kawasan Pesisir Desa Sigarpenjalin Sebagai Kawasan Strategis Kabupaten Lombok Utara
}

\author{
*Ardi Yuniarman, Agus Kurniawan, Dodik Sutikno, Osy Insyan \\ Program Studi Perencanaan Wilayah dan Kota, Universitas Muhammadiyah Mataram \\ *Ardhi.yuniard@gmail.com
}

\section{INFO ARTIKEL}

Riwayat Artikel:

Diterima: 1 1-01-2020

Disetujui: 25-02-2021

\section{Kata Kunci:}

Potensi

Kawasan

Sigar Penjalin

Pesisir

Wisata

Lombok

\begin{abstract}
ABSTRAK
Abstrak: Sektor pariwisata pada era otonomi daerah sekarang ini hanya semata-mata untuk meningkatkan Pendapatan Asli Daerah. Fenomena ini sering terjadi di dalam pengembangan dan perencanaan kawasan terutama kawasan yang berada di wilayah pesisir, sehingga perlunya penelitian ini untuk mengkaji lebih dalam terhadap potensi dan masalah yang ada di Desa Singar Penjalin, sehingga pentingnya penelitian ini untuk melihat potensi dan masalah pada kondisi fisik kawasan baik secara fisik dasar maupun fisik binaan. Metodologi penelitiaan ini menggunakan pendekatan deskriptif kwalitatif. Dari hasil yang ditemukan bahwa Kawasan Desa Singgar Penjalin merupakan kawasan pintu masuk kawasan Administrasi Perkotaan Tanjung yang melintang dari luar menuju kawasan pusat pemerintahan dengan beberapa kegiatan pariwisata dan fasilitas penunjang seperti hotel, kafe dan lapangan Golf, sudah memiliki arah pengembangan sebagai kawasan pariwisata dalam peraturan daerahnya, topografi yang variatif berpotensi memberikan atraktif sebagai kawasan wisata serta jenis tanah yang cocok sebagai fungsi pertanian. Ketidak jelasan pola pengembangan kawasan terlihat banyaknya alis fungsi lahan yang besar, susahnya mengidentifikasi kawasan akibat dari kurang kuatnya penanda kawasan dan citra sebagai ciri khas kawasan, pemanfaatan dan pembangunan fisik di area sempadan pantai yang merupakan kawasan lindung, serta akses yang masih kurang baik menuju kawasan wisata sepanjang pantai di Desa Sigar Penjalin.
\end{abstract}

\begin{abstract}
The tourism sector in the current era of regional autonomy is only to increase Regional Original Income. This phenomenon often occurs in regional development and planning, especially areas located in coastal areas, so the need for this research is to examine more deeply the potential and problems that exist in Singar Penjalin Village, so the importance of this research is to see the potential and problems in the physical condition of the area. both basic physical and built physical. This research methodology uses a qualitative descriptive approach. From the results, it was found that the Singgar Penjalin Village Area is the entrance area of the Tanjung Urban Administration area that crosses from the outside to the central government area with several tourism activities and supporting facilities such as hotels, cafes and golf courses, already has a development direction as a tourism area in its regional regulations., the varied topography has the potential to provide attractiveness as a tourist area as well as suitable soil types as agricultural functions. The unclear pattern of regional development can be seen from the large number of eyebrows of land functions, the difficulty of identifying areas as a result of the lack of strong regional markers and images as regional characteristics, physical use and development in the coastal border area which is a protected area, and poor access to the area. along the coast in Sigar Penjalin Village.
\end{abstract}

\section{A. LATAR BELAKANG}

Menurut Rahma (2017:89) Sektor pariwisata pada era otonomi daerah sekarang ini, hanya semata-mata untuk meningkatkan PAD (pendapatan asli daerah). Fenomena ini sering terjadi di dalam pengembangan dan perencanaan kawasan terutama kawasan yang berada di wilayah pesisir, sehingga perlunya penelitian ini untuk mengkaji lebih dalam terhadap potensi dan masalah yang ada di Desa Singar Penjalin.
Desa Sigar Penjalin merupakan salah satu desa yang menjadi kunjungan wisata. Sejak tahun 2005 terdapat fasilitas pendukung kegiatan pariwisata lainnya yaitu lapangan golf. Karakteristik pantai Desa Sigar Penjalin adalah pantai berpasir putih dengan warna air berupa hijau toska dan perpaduan dengan warna biru. Sejak tahun 2000-an sudah mulai terdapat pembangunan hotel dan vila yang pada saat ini terdapat sepuluh hotel dan vila yang ada di Desa Sigar Penjalin. 
Berdasarkan Peraturan Daerah (Perda.) Kabupaten Lombok Utara No. 09 Tahun 2011 tentang Rencana Tata Ruang Wilayah Tahun 2011 - 2031, Desa Jenggala masuk dalam Kawasan Strategis Kabupaten (KSP) dari sudut kepentingan pertumbuhan ekonomi dan Desa Sigar Penjalin merupakan Pusat Pelayanan Lingkungan (PPL.) yaitu pusat permukiman yang melayani kegiatan skala antar desa serta kawasan strategis kabupaten dari sudut kepentingan pertumbuhan ekonomi. Kawasan strategis di Kabupaten Lombok Utara meliputi :

i. Kawasan Strategis Sire - Medane meliputi sebagian Kecamatan Tanjung (Desa Sigar Penjalin, dan Desa Medana) dengan sektor unggulan Pariwisata;

ii. Kawasan Strategis Perkotaan Tanjung meliputi sebagian Kecamatan Tanjung (Desa Sokong, Desa Tanjung, dan Desa Jenggala) dan Sebagian Kecamatan Gangga (Desa Bentek , Desa Gondang dan Desa Genggelang); dengan sektor unggulan Perdagangan dan Jasa;

iii. Kawasan Strategis Gangga terdapat di Desa Genggelang Kecamatan Gangga seluas kurang lebih 589 Ha. Dengan sektor unggulan Perkebunan dan Agro Industri;

iv. Kawasan Strategis Agropolitan Kayangan terdapat di Kecamatan Kayangan meliputi Desa Kayangan, Desa Sesait, Desa Santong, Desa Gumantar, Desa Dangiang, dan Desa Pendua dengan sector unggulan Perkebunan dan Agropolitan; dan

v. Kawasan Strategis Carik yang terdapat di Kecamatan Bayan meliputi Desa Sukadana dan Desa Anyar perdagangan dan jasa.

Secara geografis dan topografi, kawasan Desa Sigar Penjalin meupakan kawasan pesisir. Sebelumnya wilayah peisisir belum memiliki pengertian yang baku. Tetapi berdasarkan kesepakatan umum di dunia dalam mengartikan wilayah pesisir (Coastal Zone) sebagai wilayah peralihan antara lautan dan daratan, dengan batas dari wilayah pesisir bagian daratan yaitu jarak secara arbitrer dari rata-rata pasang tinggi (mean high tide), namun batas wialayah pesisir ke arah laut yaitu batas yurisdiksi wilayah provinsi (state) pada suatu negara (Dahuri dalam Ridlo, 2019:242).

Wilayah pesisir telah didefinisikan sebagai wilayah peralihan antara ekosistem daratan dan laut yang ditentukan oleh 12 mil batas wilayah ke arah perairan dan batas kabupaten/kota kearah pedalaman. Menurut Kesepakatan umum di dunia bahwa wilayah pesisir adalah suatu wilayah peralihan antara daratan dan lautan dan hal ini termuat dalam Undangundang Republik Indonesai Nomor 27 Tahun 2007 juga menjelaskan mengenai perihal :

i. Pengelolaan Wilayah Pesisir dan PulauPulau Kecil adalah suatu proses perencanaan, pemanfaatan, pengawasan, dan pengendalian Sumberdaya Pesisir dan
Pulau-Pulau Kecil antarsektor, antara pemerintah dan Pemerintah daerah, antara ekosistem darat dan laut, serta antara ilmu pengetahuan dan manajemen untuk meningkatkan kesejahteraan masyarakat.

ii. Sumberdaya Pesisir dan Pulau-Pulau Kecil adalah sumberdaya hayati, sumberdaya nonhayati; sumberdaya buatan, dan jasajasa lingkungan; sumberdaya hayati meliputi ikan, terumbu karang, padang lamun, mangroove dan biota laut lain; sumberdaya non-hayati meliputi pasir, air laut, mineral dasar laut; sumberdaya buatan meliputi infrastruktur laut yang terkait dengan kelautan dan perikanan, dan jasajasa lingkungan berupa keindahan alam. Permukaan dasar laut tempat instalasi bawah air yang terkait dengan kelautan dan perikanan serta energi gelombang laut yang terdapat di Wilayah Pesisir.

Penentuan batas wilayah pesisir menunjukan bahwa sebenarnya garis batas dari wilayah pesisir tidak ada yang secara konkrit. Batas dari wilayah pantai didapatkan dari penentuan kondisi dan karakteristik pesisir setempat yang letaknya didasarkan pada garis imajiner. Garis batas ini berada jauh dari garis pantai, letaknya pada wilayah pesisir yang landai dengan sungai besar. Namun pantai yang curam yang berbatasan langsung dengan laut dalam memiliki wilayah peisisr yang relative sempit. (Ridlo, 2019:242)

\section{B. METODE PENELITIAN}

Penelitian merupakan penelitian deskriptif dengan menggunakan menggunakan pendekatan kwalitatif yang bertujuan membuat deskripsi atas suatu fenomena lingkungan secara faktual. Penelitian ini dilakukan untuk untuk memaparkan karakteristik potensi dan masaslah di Desa Sigar Penjalin Kecamatan tanjung Kabupaten Lombok Utara. Metode pengumpulan ddilakukan dengan dua cara yaitu pengumpulan data primer dengan melakukan observasi kawasan melalui pendekatan fisik dasar dan fisik binaan serta wawancara dan dokumentasi serta pengumpulan data sekunder mengenai pengumpulan data secara kepustakaan, dokumentasi, dan bahan lain yang relevan dengan objek penelitian.

\section{HASIL DAN PEMBAHASAN}

\section{Fisik Dasar dan Fisik Binaan.}

Berdasarkan Peraturan Menteri Pekerjaan Umum dan Perumahan Rakyat Nomor 20/PRT/M/2011 tentang apa saja yang mencakup mengenai fisik dasar dan fisik binaan, yaitu Fisik dasar yang meliputi Letak geografis, Topografi dan kemiringan, Klimatologi dan hidrologi dan Jenis tanah dan standar geologi; dan Fisik Binaan meliputi Tata guna lahan dan Status pemilikan tanah, 
Penyebaran permukiman dan Penyebaran fasilitas umum.

\section{a. Fisik Dasar}

Kondisi Geografis

Desa Sigar Penjalin adalah salah satu desa di Kecamatan Tanjung Kabupaten Lombok Utara, dengan luas daerah 1.823,83 ha. Desa Sigar Penjalin terdiri atas tiga belas dusun dan ada lima dusun yaitu, Sira Bat, Sira, Cupek, Lendang Blora dan Tembobor yang berbatasan langsung dengan pantai yang berpasi putih dan delapan dusun di kawasan perbukitan. Berikut adalah batas administrasi Desa Sigar Penjalin:
Sebelah Utara
: Laut Jawa
Sebelah Barat
: Desa Pemenang Timur
Sebelah Selatan
:Kabupaten Lombok Barat
Sebelah Timur
: Desa Medana

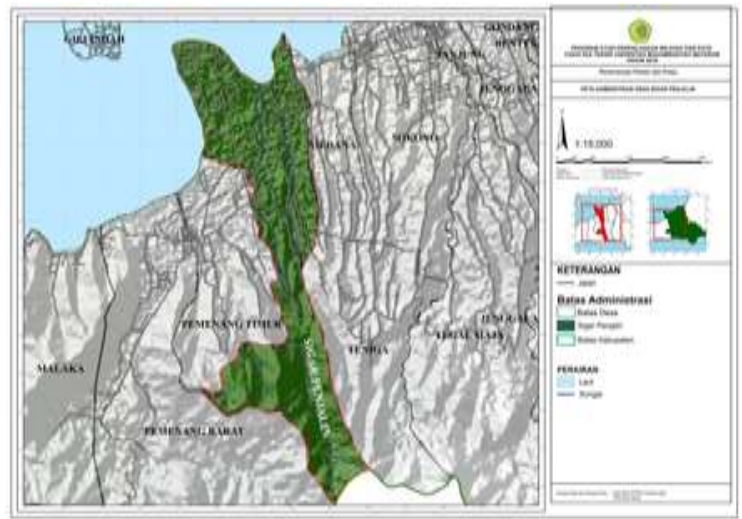

Gambar 1. Batas Administrasi Desa Sigar Penjalin Sumber : (1) RTRW Kabupaten Lombok Utara, 2011 dan (2) Peta Olahan, 2019

Kondisi Topografi

Topografi Desa Sigar Penjalin terbagi menjadi 3 kawasan yaitu :

- Kawasan pantai : pantai yang memiliki pasir putih

- Kawasan dataran : lahan pertanian yang di peruntukan untuk sawah tadah hujan dan permukiman

- Kawasan perbukitan : Sigar Pejalin juga memiliki kawasan perbukitan yang indah yang di peruntukan untuk kawasan perkebunan dan saat ini juga sudah ada pengalihan fungsi untuk pengembangan kebun binatang.

Berikut adalah tingkat kelerengan di Desa

Sigar Penjalin dengan luasannya:

- Kelerengan 0-2\% dengan luas 591,6 ha

- Kelerangan 15-25\% dengan luas 255,21 ha

- Kelerengan 25-40\% dengan luas 283,94 ha

- Kelerengan 40\%> dengan luas 629,52 ha

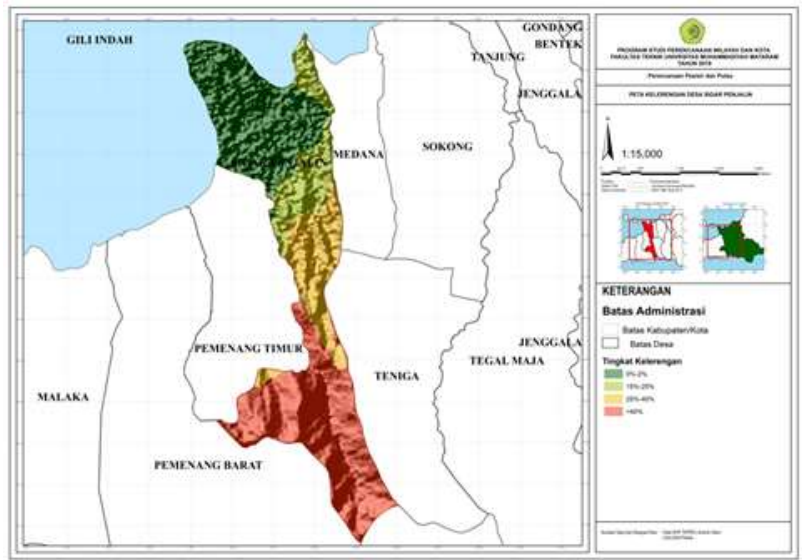

Gambar 2. Peta Kelerengan Desa Sigar Penjalin Sumber : (1) RTRW Kabupaten Lombok Utara, 2011 dan (2) Peta Olahan, 2019

Kondisi Geologi

Jenis Tanah di Desa Sigar Penjalin terdiri atas Entisol dan Andisol. Luasan jenis tenah tersebut yaitu jenis tanah Entisol dengan luas 1.045,57 ha dan jenis tanah Andisol dengan luas 777,7 ha. Berikut adalah karakteristik jenis tanah tersebut :

- Tanah Entisol adalah tanah yang masih sangat muda, yaitu baru dalam proses tingkat permulaan dalam perkembangannya, (Kata Ent berarti recent atau baru). Entisol dicirikan oleh bahan mineral tanah yang belum membentuk horison pedogenik yang nyata dan sangat baik untuk persawahan baik sawah teknis maupun tadah hujan pada daerah dataran rendah.

- Tanah Andisol adalah sebuah tanah yang memiliki horizon A molik atau horizon A umbrik yang biasanya berada diatas horizon B kambik yang terdiri atas fraksi tanah halus dan sebagian besar tersusun atas abu vulkanik, bahan piroklastik vitrik lainnya dan sangat baik untuk tanaman tanaman sayur mayur dan holtikultura.

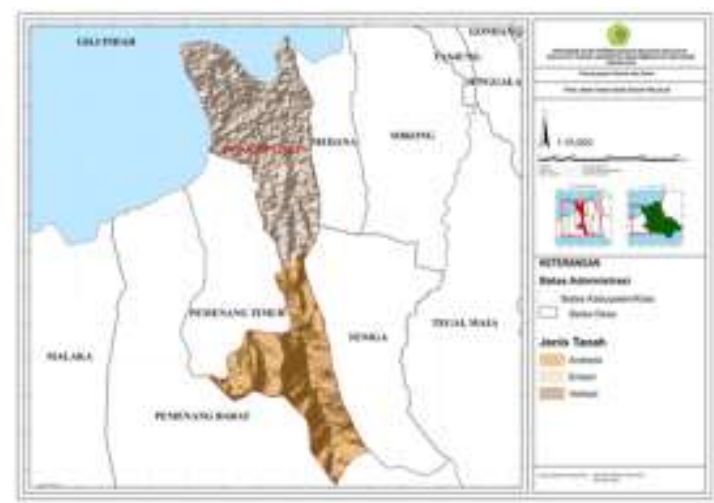

Gambar 3. Peta Jenis Tanah Desa Sigar Penjalin Sumber : (1) RTRW Kabupaten Lombok Utara, 2011 dan (2) Peta Olahan, 2019 


\section{Kondisi Hidrologi}

Desa Sigar Penjalin memiliki dua sungai besar yang menjadi batas antara Desa Sigar Penjalin dengan Desa Pemenang Timur, sungai tersebut disebut Lokok Putat. Terdapat juga sungai lain yang melintasi Desa Sigar Penjalin dan menjadi pembatas antara Dusun Tembobor dan Dusun Penjalin yang bernama Lokok Penjalin.

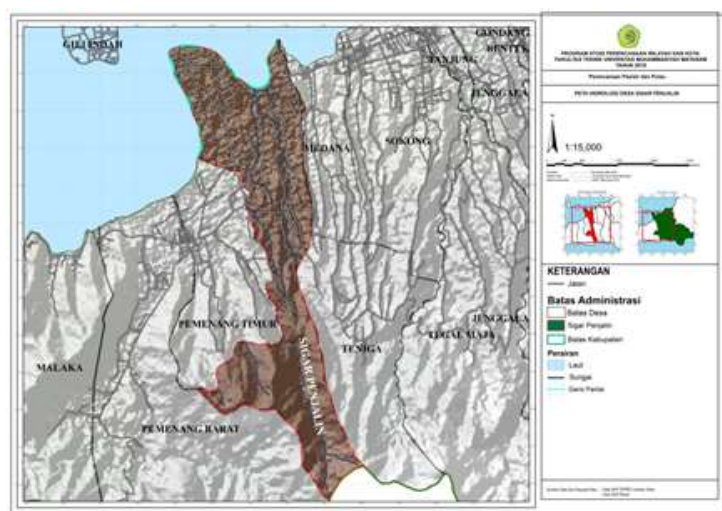

Gambar 4. Peta Hidrologi Desa Sigar Penjalin

Sumber : (1) RTRW Kabupaten Lombok Utara, 2011 dan (2)

Kondisi Klimatologi Peta Olahan, 2019

Curah hujan di Desa Sigar Penjalin terdiri atas jenis hujan ringan dengan luas daerah terkena adalah 1.356,68 ha dan jenis hujan sedang/normal adalah 466,59 ha

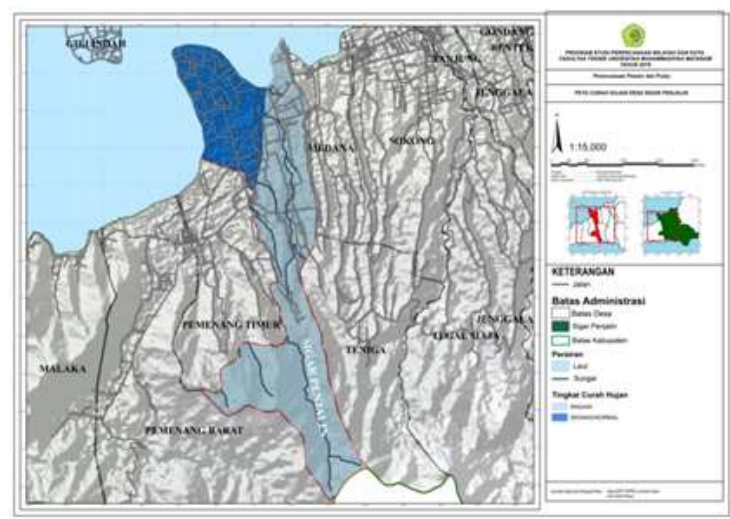

Gambar 5. Peta Klimatologi Desa Sigar Penjalin Sumber : (1) RTRW Kabupaten Lombok Utara, 2011 dan (2)

\section{Kondisi Rawan Bencana}

Jenis potensi bencana yang terdapat di Desa Sigar Penjalin, yaitu potensi bencana longsor dan potensi bencana banjir ROB. Berikut adalah rincina potensi bencana yang ada di Desa Sigar Penjalin.

- Potensi Longsor

Jenis Longsor yang terdapat di Desa Sigar Penjalin yaitu Aliran Bahan Rombakan yang sering terjadi ketika musim hujan dengan masa tanah bergerak didorong oleh air yang mengakibatkan terjadi pendangkalan di kawasan hilir sungai.

\section{- Potensi Banjir ROB}

Jenis Banjir ROB sering terjadi di kawasan sebelah selatan barat Desa Sigar Penjalin terutama di areal sungai lokok Putat, karena posisi laut yang berhadapan dengan laut lepas dengan angin yang kencang seringkali mendorong ombak mencapai $10-50$ Meter menuju darat dan biasa terjadi antara Bulan September sampai Bulan Desember.

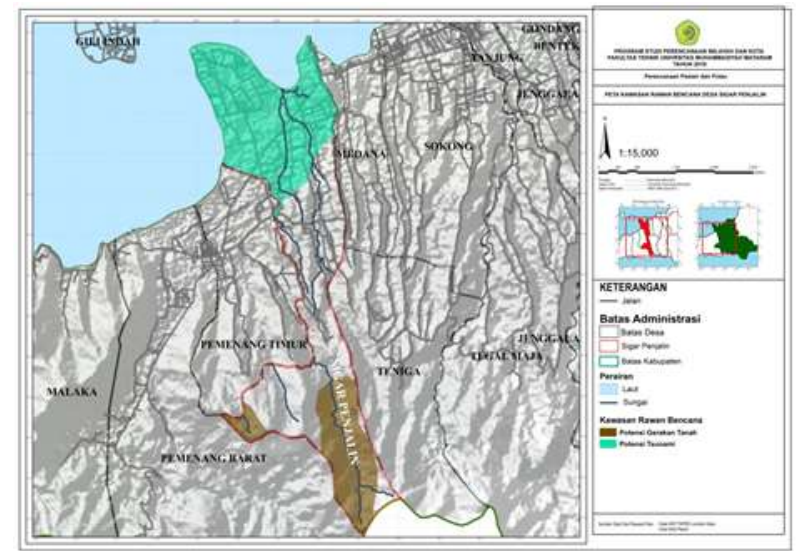

Gambar 6. Peta Rawan Bencana Desa Sigar Penjalin Sumber : (1) RTRW Kabupaten Lombok Utara, 2011 dan (2) Peta Olahan, 2019

\section{b. Fisik Binaan}

Penggunaa Lahan dan Penyebaran Permukiman Penggunaan lahan di Desa Sigar Penjalin terdiri atas permukiman, semak belukar, hutan, pertanian, dan perkebunan. Jenis penggunaan lahan yang dominan di Desa Sigar Penjalin adalah hutan dengan luas 638,2 ha, sedangkan untuk jenis lahan yang paling sedikit luasannya adalah pertanian dengan luas 10,05 ha. Berikut adalah rincian jenis penggunaan lahan di Desa Sigar Penjalin:

- Permukiman dengan luas lahan adalah 34,19 ha

- Semak Belukar dengan luas lahan adalah 30,36 ha

- Hutan dengan luas lahan adalah 638,2 ha

- Pertanian dengan luas lahan adalah 10,05 ha

- Perkebunan dengan luas lahan adalah 67,19 ha

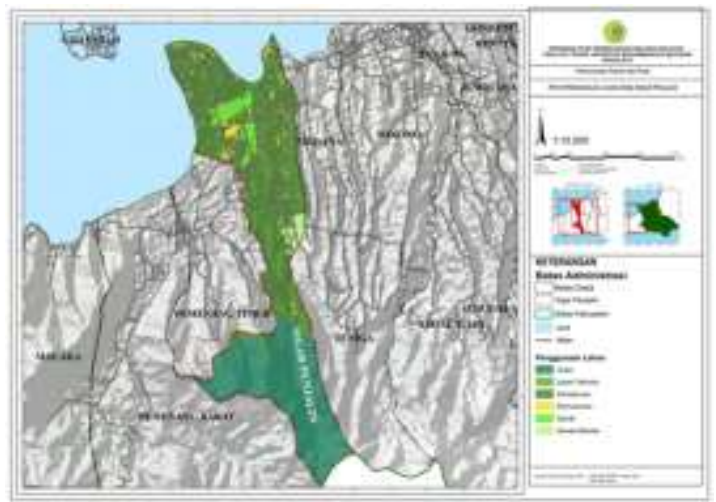


Gambar 7. Peta Jenis Penggunaan Lahan Desa Sigar Penjalin.

Sumber : (1) RTRW Kabupaten Lombok Utara, 2011 dan (2) Peta Olahan, 2019

Aktifitas pada kawasan pesisir dilihat dari sebaran permukiman yang ada di kawasan pesisir Sigar Penjalin serta batas wilayah bisa melalui jalan dan sungai maupun batas wilayah administrasi, serta kemampuan laha pada kawasan pesisir untuk mengembangkan kawasannya, sehingga dapat digunakan pada pengembangan tahun-tahun berikutnya.

Jika dilihat dari sebaran permukiman, pemukiman di kawasan pesisir merupakan permukiman yang langsung berdekatan dengan pantai, tepatnya di Dusun Sira Barat dan Tembobor, sedangkan permukiman dusun lainnya berada jauh dengan pantai (pesisir) dan dengan pembatasnya berupa lahan yang dikelola warga berupa kebun kelapa dan kebun ubi. Pada kawasan pesisir terdapat bangunan perhotelan. Dan adanya hotel-hote dan vila tersebut mendominasi kawasan pantai, selain itu pula terdapat lapangan golf melingkar yang berada di kawasan Pantai Sira yang letaknya dikelilingi oleh pemukiman warga.

Sedangkan untuk pola pemukiman, pada permukian di kawasan pesisir pantai Sigar Penjalin memiliki pola pemukiman yang tersebar dan mengikuti pola jalan dan serta dengan ritme tidak beraturan dan organik.

\section{Sebaran Fasilitas Umum dan Sosial}

Pada kawasan pesisir terdapat fasilitas umum dan fasilitas sosial yang tersebar di kawasan. Fasilitas umum yang terdapat di kawasan pesisir Sigar Penjalin adalah gardu listrik, jalan kolektor desa, pelabuhan alternatif tiga gili, jalan setapak menuju kawasan pesisir, dan persampahan. Sedangkan untuk fasilitas sosial di kawasan pesisir Sigar Penjalin berupa fasilitas perdagangan di pantai berupa warung-warung kecil, lahan terbuka berupa fasilitas golf, hotel dan vila (tempat penginapan), fasilitas pendidikan, failitas peribadatan berupa mushola dan masjid, serta fasilitas kesehatan berupa polindes. Berikut adalah rincian fasilitas umum dan fasilitas sosial yang ada di kawasan pesisir Sigar Penjalin.

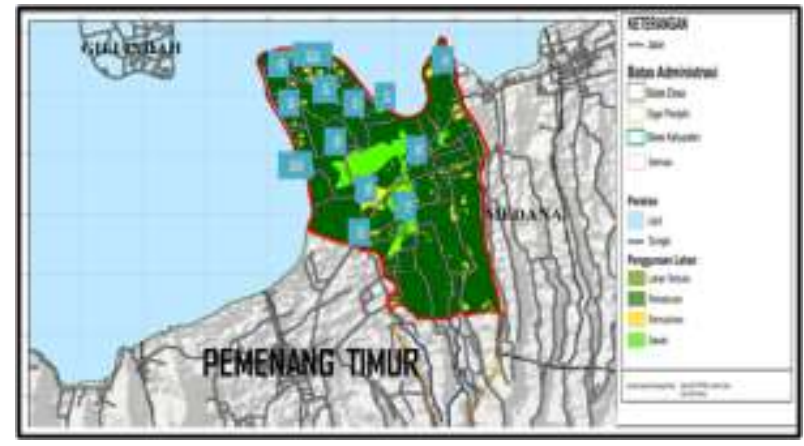

Gambar 8. Peta Sebaran Fasum dan Fasos Kawasan Pesisir Desa Sigar Penjalin

Sumber : (1) RTRW Kabupaten Lombok Utara, 2011 dan (2) Peta Olahan, 2019

\section{Potensi dan masalah}

\section{a. Fisik Dasar}

Secara fisik dasar Desa Sigar Penjalin dari hasil analisis memeiliki beberapa potensi dan masalah anatara lain :

Potensi :

- Secara administrasi merupakan gerbang masuknya Kecamatan Tanjung, dan telah ditetapkan sebagai kawasan wisata yaitu pada Peraturan Daerah Kabupaten Lombok Utara Nomor 9 Tahun 2011 Tentang Rencana Tata Ruang Wilayah Kabupaten Lombok Utara Tahun 2011-2031.

- Merupakan "Kawasan Strategis Daerah Sire Medane meliputi sebagian Kecamatan Tanjung (Desa Sigar Penjalin, dan Desa Medana) dengan sektor unggulan Pariwisata"

- Deliniasi kawasan pesisir berada di topografi o$2 \%$ dan 10-25\%, yang masih dapat difungsikan sebagai kawasan budidaya .

- Memiliki kawasan perbukitan dan pantai yang mulai di lakukan pengembangan sarana dan prasarana penunjang pariwisata dan perdagangan.

- Jenis tanah di kawasan pesisir merupakan entisol yaitu jenis tanah yang dapat digunakan untuk permukiman dan pertanian.

- Terdapat 1 sungai yang berbatasan dengan Desa Pemenang Timur, yaitu Lokok Putat, serta 1 sungai lainnya yang berada di kawasan pesisir Sigar Penjalin.

- Curah hujan pada kawasan merupakan ringan dan sedang/normal sehingga hasil perkebunan desa Sigar Penjalin berupa Ubi dan mente sangat bagus.Pengetahuan Lokasi kerawan bencana desa akan memberikan pemahaman dalam merencanakan wilayah mana yang boleh di kembangkan dan di lindungi.

- Memberikan gambaran pengembangan dan perencanaan wilayah yang bisa membantu konsep adaptasi dan mitigasi bencana.

Masalah :

- Pengelolaan antara kawasan Hulu dan Hilir di desa Sigar Penjalin belum saling mendukung.

- Ketidak jelasan batasan wilayah antar desa sehingga susah untuk mengidentifikasi wilayah administrasi.

- Terjadi pengalihan fungsi lahan dari perkebunan ke bangunan perhotelan dan sarana wisata dan kawasan pertanian mejadi perumahan dan perdagangan khususnya kawasan lereng. 
- Terjadi pengalihan fungsi lahan pertanian dan perkebunan menjadi golf dan bangunan perhotelan.

- Air sungai sudah keruh dgn debit air tidak menentu musim hujan besar dan musim panas mengecil bahkan kering.

- Curan hujan yang ringan \& sedang hingga jenis pertanian pertanian tadah hujan.

- Pengalihan Fungsi lahan uang cukup tinggi

- Aktifitas Penebangan Hutan di Kawaasan Hulu sungai mengakibatkan terjadi pendangkalan di kawasan hilir sungai akibat sedimentasi dasar sungai yang terbawa air sungai ke hilir.

- Jenis Banjir ROB sering terjadi di kawasan sebelah selatan barat Desa Sigar Penjalin terutama di areal sungai lokok Putat, karena posisi laut yang berhadapan dengan laut lepas dan Pendangkalan sungai serta belum adanya dinding pantai.

b. Fisik Binaan

Berdasarkan fisik Binaan hasil analisis memeiliki beberapa potensi dan masalah anatara lain :

Potensi :

- Merupakan kawasan Perkotaan Tanjung yang melintas jalan Nasional dan Provinsi atau jalan Arteri dan jenjang Kelas Jalan Ke 1.

- Waktu tempuh dari jalan kolektor sekunder menuju pesisir adalah kurang lebih 5 menit.

- Pergerakan eksternal masyarakat kawasan pesisir Sigar Penjalin ke kawasan lain berupa kegiatan pemenuhan kebutuhan sehari-hari (mendasar), seperti memenuhi kebutuhan akan perdagangan dan jasa, pendidikan, kesehatan dan lainnya.

- Penggunaan lahan di kawasan pesisir berupa lahan terbuka, permukiman, perkebunan dan sawah.

- Memiliki batasan yang jelas terhadap deliniasi peruntukan akwasan pesisir dan daratan bisa menjadi arahan jenis pembanguan yang akan di lakukan berdasarkan karakter kawasan.

- Memiliki batasan wilayah dan kejelasan pemanfaatan ruang terlihat dari kecenderungan pola masa bangunan dalam pemanfaatan lahan memudahkan masyarakat dan pemerintah untuk membuat perencanaan dan penganggaran pembangunan berdasarkan kondisi eksisting wilayah dan karakter masyarakatnya.

- Fasilitas penginapan bagi turis berupa hotel dan villa dengan luas total adalah 96 ha, lokasi berada Dusun Sira, Dusun Sira Bat dan Dusun Tembobor. terdapat lapangan golf yang berada di Dusun Sira Bat dan Sira Daya dengan luas 250 ha, yang dikelola oleh perusahaan Golf Posaido Country Club

Masalah :
- Perbedaan akses jalan utama dan akses menuju kawasan dalam belum jelas serta minimnya public isgnage yang menjelasan arah tujuan dari jalan tersebut.

- Susahnya mengidentifikasi jalan dari dan menuju lokasi wisata secara jelas.

- Masih ada jalan menuju kawasan pantai dan jalan yang belum ada penerangan jalannya

- Belum adanya saran transportasi public yang memadai dan terjadwal yang masuk di kawasan pesisir pantainya.

- Belum adanya lokasi parkir bagi kendaran yang memadai di kawsan ekonomi dan kawasan pariwisata di pesisir pantai.

- Terdapat penggunaan lahan berupa perkebunan, permukiman (hotel dan rumah warga) di area sempadan pantai.

- Deliniasi kawasan lindung dan budidaya yang belum jelas serta banyaknya masyarakat yang tidak memahami fungsi kawasan terhadap konteks pembangunan yang akan dilakukan.

- Terdapat beberapafasilitas penginapan berupa hotel dan villa yang berada di sempadan pantai yang mengambil kawasan pantai sehingga tidak bisa di akses oleh masyarakat.

\section{SIMPULAN DAN SARAN}

Kesimpulan dari hasil analisis mengenai potensi dan masalah pada Fisik Dasar dan FisikBinaan di Desa Sigar Penjalin sebagai Pintu Gerbang masuknya ke Kecamatan Tanjung sebagai Kawasan Perkotaan Administrasi Kabupaten Lombok Utara sebagai berikut :

- Kawasan Desa Singgar Penjalin merupakan kawasan pintu masuk akwasan Administrasi Perkotaan Tanjung yang melintang akses utama masuk kawasan pusat Perkotaan, merupakan kawasan pesisir yang memiliki beberapa fasilitas penunjang seperti hotel, kafe dan lapangan Golf, sudah memiliki arah pengembangan sebagai kawasan pariwisata dalam peraturan daerahnya, topografi yang variatif berpotensi memberikan daya tarik/atraktif sebagai kawasan wisata serta jenis tanah yang cocok sebagai fungsi pertanian.

- Ketidak jelasan pola pengembangan kawasan terlihat banyaknya alis fungsi lahan yang besar, susahnya mengidentifikasi kawasan akibat dari kurang kuatnya penanda kawasan dan citra sebagai ciri khas kawasan, pemanfaatan dan pembangunan fisik di area sempadan pantai yang merupakan kawasan lindung, serta akses yang masih kurang baik menuju kawasan wisata sepanjang pantai di Desa Sigar Penjalin.

- Berdasarkan beberapa hasil kesimpulan yang telah dijelaskan sebelumnya, memberikan harapan sebagai berikut adalah :

- Bagi pemerintah perlu adanya berbagai program dan perencaan lanjutan sebagai arah 
pengembangan kawasan sehingga kawasan memiliki identitas yang kuat sebagai kawasan pariwisata dan perkotaan Tanjung serta pengembangan kawasan yang bisa menunjang aktifitas ekonomi masyaratat secara mandiri yang bertujuan untuk meningkatkan Sumber Daya Manusia yang ada serta memberikan peluang bagi masyarakt agar dapat mengelola kawasannya sendiri, sehingga dapat memaksimalkan potensi yang tersedia, serta dapat meningkatkan kesejahteraan masyarakat. Selain itu, pemerintah perlu mendorong keluarnya peraturan daerah terkait tata kelola kawasan pesisir yang bisa menjadi payung hukum pengelolaan hak-hak publik dan atas kawasan lindung di pesisir.

- Bagi masyarakat perlu adanya kesadaran diri untuk dapat mengembangkan diri, sehingga dapat membangun kawasan serta meningkatkan kesejahteraan diri masing-masing.

\section{DAFTAR RUJUKAN}

[1] Peraturan Menteri Pekerjaan Umum dan Perumahan Rakyat Nomor 20/PRT/M/2011.

[2] Peraturan Daerah (Perda.) Kabupaten Lombok Utara No. 09 Tahun 2011 tentang Rencana Tata Ruang Wilayah Tahun $2011-2031$

[3] Rahma, P. D. Dan Aldila, Rifky (2017). Jurnal Reka Buana Volume 2 No 1, 2017. ISSN 2503-2682 dan ISSN 2503-3654.

[4] Ridlo, M.A. (2019). Jurnal Planologi Vol. 16, No. 2, Oktober 2019, P-ISSN : 1829-9172 / E-ISSN : 26155257 . 